\title{
Evaluation of Black Tea Consumption In Terms Of Substance Use Disorders, Sleep Quality, and Mental Symptoms among Medical Students
}

\author{
Kader Semra Karatas \\ Recep Tayyip Erdogan University, Medical Faculty Psychiatry Department, Rize, Turkey \\ Email: drsemraidil@gmail.com, semra.karatas@erdogan.edu.tr \\ Orcid.org/0000-0003-3595-8019
}

\begin{abstract}
Aim

This study aimed to investigate black tea consumption, substance use disorders, sleep disorders, and psychological symptoms among medical students of various ages and grades.

\section{Materials and methods}

The study involved face-to-face interviews of 356 students which is accepted study from 650 medical students, including 101 participants daily consuming black tea. Addiction Profile Risk Screening Index (BAPI-T), Pittsburgh Sleep Quality Index, and Psychiatric Symptom Check List-90 were applied to the students. The Addiction Profile Index was administered to individuals found to be at risky consumption using BAPI-T.
\end{abstract}

\section{Results}

Although $72.3 \%$ of the participants had a risk for addiction profile, $27.7 \%$ had none. Further, $50.1 \%$ of substance users were first grade, and being in the first grade increased substance use 9896 times. $73 \%$ of the people who said that they drank black tea every day met the diagnostic criteria of addiction. Sleep quality was found to be low in the group with and without addiction profile risk. Anger status was high in patients with impaired sleep quality without risk of addiction profile. A significant difference was found between the effect on life and craving behavior in substance use groups and API subscales.

\section{Conclusions}

Especially in eastern cultures where black tea consumption is consumed, the approach is important considering the risk of addiction profile. Being in the first grade is a risk factor for substance abuse such as tea. Psychological symptom screening is important for university students.

Keywords: Caffeine, psychological symptom, sleep quality, tea

\section{Special Issue of Health Sciences}

DOI: $10.7176 / \mathrm{JSTR} / 6-03-07$

\section{Introduction}

Individuals in pre- or early adulthood had higher levels of experience, including adaptation, socialization, existence in society alone, transition to independence, self-esteem, self-determination, and more prominent academic performance. Legal and/or illegal substance use is among the most prominent attitudes and behaviors among people in this process $(1,2)$. The World Health Organization stated that substance abuse, mental problems, and risky behaviors are frequently seen as an important developmental process in pre- or early adulthood (3). While substance use can lead to many conditions such as anxiety or depressive disorders and sleep disturbances (4.5), psychiatric disorders or sleep disturbances can be facilitating factors for substance use (6-8). The use of addictive substances is a problem that the whole world has difficulty in coping with $(1,6)$. Although many of the published studies focused on the use of 
illicit substances, the studies on tea consumption, which are thought to be less harmful, are scarce. Some effects of tea, coffee on mood, attention, concentration, and sleep direct people to these items in the community section where academic performance is higher $(4,9)$.

The habit of tea drinking is a quite common and important cultural feature in Turkey and Asian countries $(5,10,11)$. Caffeine-containing substances such as tea, coffee depending on the consumed, can seen several effects on sleep wake cycle, nervousness, restlessness, depression, anxiety, and cognitive functions. Increased, decreased, or discontinued caffeine consumption-related changes in biological, psychological, and other functions may affect a person's life and disrupt functionality (12-19). Considering these effects of caffeine, caffeine use disorder is not defined in the Diagnostic and Statistical Manual of Mental Disorders-5 (DSM-5) (18).

Substance such as tea, which is easy to reach, seem harmless and can create impairments of use over time. Studies on whether substances such as tea cause substance use disorder are quite few. Disorders of the use of these substances can lead to changes in the sleep and wake cycle and mental state. Hence, substance use such as black tea use, substance use disorders, sleep disorders, and psychological symptoms among students of various ages and grades were investigated in education units, such as medical faculties, where education and academic performance were intense.

\section{Material and Methods}

\section{Design of the study}

This was a cross-sectional epidemiological study.

\section{Universe, sample, and data collection}

The universe of the study consisted of 650 female and male students educated at a university hospital medical school. The participants were informed about the study and those who gave written consent were included. 356 people who agreed to participate in the study were interviewed face to face. A total of 101 participants consuming caffeine-containing substances such as chocolate, cocoa, energy drinks, green tea, oolong tea, coffee and various drugs $\leq 2$ times per week; and those daily consuming black tea constituted the sample. Further, 255 students were excluded from the study because they did not meet the inclusion criteria. Addiction Profile Risk Screening Index (BAPI-T), Pittsburgh Sleep Quality Index (PSQI), and Psychiatric Symptom Check List-90 (SCL-90) were applied to the male and female students of the sample. The Addiction profile index (API) was administered to people found to have more than five cups $(200 \mathrm{~mL})$ of black tea consumption using BAPI-T. Addiction severity was evaluated according to the total API score. The participants were divided into two groups: Group 1 was the group with no risk for addiction profile, and tea consumption was less than 5 cups per day. Group 2 was the group with tea consumption was more than 5 cups per day evaluated in the group with risk for addiction profile.

Clinical data were evaluated by studying the sleep quality and psychological symptoms of the individuals who were diagnosed with substance use disorder as a result of BAPI applied to the groups whose risk for addiction profile was determined and BAPI subscale was compared. Sleep quality and psychological symptom inventory of the individuals in the group with no risk for addiction profile were evaluated.

\section{Selection of the participants}

The inclusion criteria were as follows:

1. Age between 17 and 65 years

2. Consumption of caffeine-containing substances and caffeine-containing drugs such as chocolate, cocoa, energy drinks, coffee, and various drugs, $\leq 2$ times per week

3. Daily consumption of black tea

4. Absence of organic/non-organic mental disorder

The exclusion criteria were as follows:

1. Age less than 18 years

2. Consumption of caffeine-containing substances and caffeine-containing drugs such as chocolate, cocoa, energy drinks, coffee, and various drugs, $>2$ times per week

3. Psychotropic substance or drug use

4. Amnestic disorders such as mental retardation, dementia, delirium, and others that could be determined by medical evaluation

\section{Data collection tools}

1. Addiction Profile Risk Screening Index (BAPI-T): It was designed to determine the risk level of alcohol-substance use. It was used in studies with a general population, all of which did not

47 I $P$ a g e 
use substances. It consisted of two scales: alcohol and substance. It had 22 questions. A detailed assessment should be performed in cases with risk levels determined using BAPI-T. The Cronbach alpha coefficient of the scale was 0.88 . The item-total score correlation coefficients were between 0.86 and 0.89 . In the explanatory factor analysis, one factor with an eigenvalue greater than 1 was obtained, which explained $64.7 \%$ of the total variance (8).

2. Addiction Profile Index (API): It is a self-report scale consisting of 37 questions and 5 subscales. The subscales measured substance use characteristics, diagnostic criteria for addiction, effect of substance use on the person's life, craving for substance use, and motivation to quit substance use. The total API score measured the severity of dependence. Each subscale was scored within itself. The score of each subscale determined the total API score of equal weight. The reason for this was the assumption that each subscale affected the severity of addiction differently. The substance use property subscale evaluated all substances, alcohol and non-alcohol, and the problems caused by the substance used. The addiction diagnostic criteria included in DSM and International Classification of Diseases-10 (ICD-10) were examined in the addiction diagnostic criteria subscale. The effect of substance uses on a person's life subscale included questions investigating both psychosocial functions and other effects of the substance on a person's life. The subscale of the intention to use substance evaluated craving. The subscale of motivation to quit substance use included questions that measured a person's motivation level. Increased motivation to quit was evaluated as having excessive addiction problems. Therefore, although motivation was an important factor for treatment, it was considered as a factor that showed the increased severity of addiction (8).

3. Psychological Symptom Check List-90 (SCL-90): It was a measure that determined the level of psychological symptoms in individuals and which areas they spread to. The subscales of SCL90, including Somatization, Obsessive-Compulsive, Interpersonal Sensitivity, Depression, Anxiety, Anger-Hostility, Phobic Reaction, Paranoid Thought, and others, consisted of 10 symptom groups. The four response categories were a self-disclosure inventory, with five response scales developed from "none," to "advanced," marked 0-1-2-3-4 and indicating the degree of occurrence (20).

4. Pittsburgh Sleep Quality Index (PSQI): It was a scale that provided information about sleep quality and type and severity of sleep disorder in the last month. It was developed in 1989 by Buysse et al. Of the 24 questions in the scale, 19 were self-report questions. The remaining five questions were answered by the bed partner or roommate, if any. The Turkish validity and reliability study of the scale was conducted by Agargun et al. The component-total score correlation coefficients were found to be $0.22-0.77$, and the test-retest reliability was $0.93-0.98$ (21).

\section{Statistical analysis}

The data were analyzed using the SPSS- 24 package program. Descriptive statistics were expressed as frequency distributions, arithmetic means, and standard deviations. The distribution properties of continuous variables were evaluated using the Kolmogorov-Smirnov test. The continuous variables were compared with categorical variables, and Mann-Whitney $U$ and Kruskal-Wallis $H$ tests were applied. The chi-square test was used to evaluate the relationship between two categorical variables. In all analyses, the type 1 error margin ( $P$ value) was accepted as 0.05 .

\section{Ethics committee approval}

The study was started after the approval (239, numbered 2018/197, and dated December 26, 2018) from the Non-Interventional Clinical Research Ethics Committee of Recep Tayyip Erdogan University Faculty of Medicine.

\section{Results}

A total of 101 people (54 females and 47 male) participated in the study. Of these, $28(27.7 \%)$ had no risk for addiction profile. Further, $16(57.1 \%)$ were male. Seventy-three students $(72.3 \%)$ found to be risky for addiction profile. Also, $42(57.5 \%)$ of the substance users were female and $31(42.5 \%)$ were male. Of substance users, $50.1 \%$ were first-grade. No statistically significant difference was observed between substance use and sex. A significant difference was found between substance use and grades of students (Table 1). Being in the first grade increased substance use 9896 times (Table 2). Further, 46 of 73 people $(63 \%)$ who said that they drank tea every day met the addiction diagnostic criteria (Table 3 ). 
Table 1. Sociodemographic characteristics of groups

\begin{tabular}{|c|c|c|c|c|c|c|}
\hline & \multicolumn{2}{|c|}{ Group $1(n=28)$} & \multicolumn{2}{|c|}{ Group $2(n=73)$} & \multirow[t]{2}{*}{$\chi^{2}$} & \multirow[t]{2}{*}{$P$} \\
\hline & & $\%$ & & $\%$ & & \\
\hline Sex & & & & & & \\
\hline Female & 12 & (42.9) & & $(57.5)$ & 5.17 & 0.15 \\
\hline Male & 16 & (57.1) & 31 & $(42.5)$ & & \\
\hline 1.Grade & 13 & $(12,6)$ & 38 & $(37,5)$ & & \\
\hline $\begin{array}{l}\text { Other Grades } \\
(2 ., 3 ., 4 ., 5 ., 6 .)\end{array}$ & & (15.3) & 35 & (34.6) & 16.73 & 0.00 \\
\hline
\end{tabular}

$\chi^{2}$, Chi-square test; $n$, number of patients; $\%$, percentage.

Table 2. Predictive factors determining substance use

\begin{tabular}{|c|c|c|c|c|c|c|c|}
\hline & B & SE & Wald & df & $\begin{array}{c}\text { OR } \\
(\operatorname{Exp}(\mathbf{B}))\end{array}$ & \%95 CI & $\boldsymbol{P}$ \\
\hline First grade & 2.292 & 0.524 & 19.1 & 1 & 9.896 & $3.543-7.640$ & $\mathbf{0 . 0 0}$ \\
\hline
\end{tabular}

OR, Odds ratio; CI, confidence interval.

Table 3. Substance user group and addiction level

\begin{tabular}{|c|cc|c|c|}
\hline & \multicolumn{2}{|c|}{ Group2 } & \multirow{2}{*}{$\boldsymbol{\chi}^{\mathbf{2}}$} & $\boldsymbol{P}$ \\
\hline None & $\boldsymbol{n}$ & $\mathbf{\%}$ & & \\
\hline Low & 27 & 37 & & \\
\hline Middle & 6 & 82.9 & \multirow{2}{*}{17.1} & $\mathbf{0 . 0 4}$ \\
\hline Advanced & 16 & 21.9 & & \\
\hline
\end{tabular}

$\chi^{2}$, Chi-square test; $n$, number of patients; \%, percentage.

The sleep quality was found to be impaired in $75 \%$ of no risk for addiction profile and 87.7 of risk for addiction profile (Table 4). In the psychological symptom scans of no risk for addiction profile individuals, the anger subscale was found to be significantly different compared with other subtitles (Table 5).

Table 4. Comparison of students with and without risk for Addiction Profile and PSQI

\begin{tabular}{|c|c|c|c|c|c|c|}
\hline & \multicolumn{2}{|c|}{ Without risk } & \multicolumn{2}{|c|}{ With risk } & \multirow[t]{2}{*}{$\chi^{2}$} & \multirow[t]{2}{*}{$P$} \\
\hline & & $\%$ & $n$ & $\%$ & & \\
\hline PSQI $\geq 5$ & & $(75)$ & 64 & $(87.7)$ & \multirow{2}{*}{\multicolumn{2}{|c|}{$\begin{array}{l}0.11 \\
0.13\end{array}$}} \\
\hline PSQI $\leq 5$ & 7 & (25) & 9 & (12.3) & & \\
\hline
\end{tabular}

$\chi^{2}$, Chi-square test; $n$, number of patients; $\%$, percentage. 
Table 5. Comparison of SCL-90 subscales in sleep quality-impaired individuals without substance use

\begin{tabular}{|c|cc|c|c|}
\hline & \multicolumn{2}{|c|}{$\begin{array}{c}\text { Group 1 }(\boldsymbol{n}= \\
\text { 21) }\end{array}$} & $\chi^{\mathbf{2}}$ & $\boldsymbol{P}$ \\
\hline & $\boldsymbol{n}$ & $\mathbf{\%}$ & & \\
\hline SCL-90 & 21 & 75 & & 0.52 \\
\hline Somatization & 2 & 9.5 & 13.98 & 0,06 \\
\hline $\begin{array}{c}\text { Obsessive }- \\
\text { Compulsive }\end{array}$ & 3 & 14,3 & 29.6 & 0.73 \\
\hline Sensitivity & 2 & 9.5 & 10.31 & 0.06 \\
\hline Depression & 3 & 14.3 & 29.6 & 0.64 \\
\hline Anxiety & 1 & 4.8 & 7.86 & 0,64 \\
\hline Phobia-anxiety & 1 & 4,8 & 7,86 & $\mathbf{0 . 0 1}$ \\
\hline Anger & 6 & 28.6 & 20.6 & 0.11 \\
\hline Paranoid & 4 & 19 & 14.55 & 0,64 \\
\hline Psychoticism & 1 & 4,8 & 7,86 & \\
\hline
\end{tabular}

$\chi^{2}$, Chi-square test; $n$, number of patients; \%, percentage.

No significant difference was found while comparing SCL-90 and PSQI clinical scales with risk for addiction profile group (Table 6). A significant difference was found between the effect on life and craving behavior in substance use group and API subscales (Table 7).

Table 6. Comparison of SCL-90 with and without substance use

\begin{tabular}{|l|l|l|l|}
\hline & Group 1 $(\boldsymbol{n}=\mathbf{2 8})$ & Group 2 $(\boldsymbol{n}=\mathbf{7 3})$ & $p$ \\
\hline SCL-90 & Mean \pm SD & Mean \pm SD & \\
\hline Somatization & $0.58 \pm 0.48$ & $0.41 \pm 0.21$ & 0.25 \\
\hline $\begin{array}{l}\text { Obsessive - } \\
\text { Compulsive }\end{array}$ & $1.07 \pm 066$ & $0.93 \pm 0.52$ & 0.44 \\
\hline Sensitivity & $0.70 \pm 0.58$ & $0.65 \pm 0.24$ & 0.97 \\
\hline Depression & $0.76 \pm 0.65$ & $0.42 \pm 0.16$ & 0.44 \\
\hline Anxiety & $0.48 \pm 0.40$ & $0.48 \pm 0.27$ & 0.28 \\
\hline Phobia-anxiety & $0.23 \pm 0.26$ & $0.12 \pm 0.12$ & 0.72 \\
\hline Anger & $0.47 \pm 0.45$ & $0.45 \pm 0.38$ & 0.36 \\
\hline Paranoid & $0.55 \pm 0.53$ & $0.60 \pm 0.36$ & 0.65 \\
\hline Psychoticism & $0.34 \pm 0.45$ & $0.22 \pm 0.20$ & 0.75 \\
\hline Conclusion & $0.66 \pm 0.56$ & $0.49 \pm 0.58$ & 0.16 \\
\hline PSQI & $1.03 \pm 0.18$ & $1.00 \pm 0.00$ & 0.71 \\
\hline
\end{tabular}

Mean $\pm \mathrm{SD}$ : Mean \pm standard deviation Mann-Whitney U test 
Table 7. Substance use disorder and API subscale comparisons

\begin{tabular}{|c|c|c|}
\hline & $\begin{array}{c}\text { Group 2 (Mean } \pm \\
\text { SD) }\end{array}$ & $\boldsymbol{P}$ \\
\hline $\begin{array}{c}\text { Properties of } \\
\text { substance use }\end{array}$ & $0.55 \pm \mathbf{0 . 5 8}$ & 0.06 \\
\hline $\begin{array}{c}\text { Addiction } \\
\text { diagnosis }\end{array}$ & $1.73 \pm \mathbf{2 . 7}$ & 0.13 \\
\hline Impact on life & $3.9 \pm \mathbf{5 . 2}$ & $\mathbf{0 . 0 0}$ \\
\hline Craving & $2.4 \pm \mathbf{3 . 1}$ & $\mathbf{0 . 0 0}$ \\
\hline $\begin{array}{c}\text { Motivation to } \\
\text { quit }\end{array}$ & $1.8 \pm \mathbf{3 . 3}$ & 0.25 \\
\hline Total & $10.6 \pm \mathbf{1 2 . 9}$ & $\mathbf{0 . 0 0}$ \\
\hline
\end{tabular}

Mean \pm SD: Mean \pm standard deviation,

\section{Discussion}

This study was performed to investigate with black tea consumption, and substance use disorders, sleep disorders, and psychological symptoms among medical students of various ages and grades. In the present study, $73 \%$ of medical students who drank black tea every day, met the diagnostic criteria of addiction. Black tea consumption was significantly higher in first-grade medical students, with substance use increased 9896 times. The use of stimulants increased with the increase in academic performance in pre-adulthood existence in the society, independence, and adaptation process $(2,4,22)$. A study exploring the relationship between tea-coffee consumption and cognitive performance showed that caffeine consumption improved cognitive performance (23). A study conducted on 78 university students examined the relationship between caffeine consumption and study habits, revealing that caffeine consumption had a positive relationship with more efficient working habits and lower anxiety levels (24). Tseng et al. (2014) stated that university students, especially in the pre-doctoral training period, drank tea more than other caffeine-containing drinks compared with other grades (5). Especially consuming caffeine-containing drinks in earlier ages increased the consumption of caffeine-containing coffee-based drinks in early adulthood (25). The substance use was significantly higher among the first-grade students compared with the other grades in the present study, can supporting the adaptation behavior experienced during the period of self-development in terms of independence and increase in academic performance. Since studies on caffeine-containing beverages were generally based on coffee consumption, it was important to evaluate the consumption of tea-based caffeine-containing beverages. Based on the sociocultural structure, the consumption of substances such as tea and, relatively less, coffee often coincides with childhood and adolescence in Turkey and other Asian countries. The increase in consumption of these soft substances in early adulthood might be because people thought that these substances were relatively harmless compared with other stimulants.

In many studies, substance use was found to be more common in male sex (26), although some emphasized its predominance in female sex (27). However, some others indicated no difference in the relationship between caffeine consumption and sex $(24,26)$. The present study supported the fact that substance use was observed more frequently in female sex as in some other studies, but it emphasized the necessity of studies involving a larger number of sample groups and various cultures.

In the present study, the sleep quality was found to be impaired in $75 \%$ of the participants who were not risky for addiction profile. In the psychological symptom screening scale, the anger subscale was found to be significantly different in the group which were no risk for addiction with low sleep quality. Studies have shown that the sleep quality of people who are educated especially in the field of health is poor. Psychosocial stress factors affect sleep quality (28-30). A study evaluating the sleep of individuals with poor anger control using sleep diaries and actigraphy emphasized that inadequate anger control was the most important determinant of sleep quality deterioration (31). Anger increased wakefulness during the day, and this condition also interrupted sleep as arousal during sleep (32). Anger aggravated sleep quality, while impaired sleep quality increased anger (33). Street et al. (2016) screened the sleep quality of 1878 16-year-old high-school students and showed that those with low sleep quality had problems in anger control (34). In the present study, results supported the findings of similar previous studies. However, 
the use of better inventory or scales to evaluate the conditions affecting sleep quality, such as personality and behavior characteristics, by increasing the number of samples would be more appropriate.

The sleep quality was found to be impaired in $87.7 \%$ of the participants who were risky for addiction profile. A study conducted by Ergun et al. (2017) with university students emphasized that the grade of students, presence of psychological disorder, and consumption of five cups or more of tea and coffee per day adversely affected sleep quality (15). In another study conducted in Turkey, coffee consumption did not affect sleep quality, while tea consumption was reported to impair sleep quality (35). Zunhammer et al. (2014) examined the sleep quality of university students during the examination period and stated that caffeine consumption did not affect sleep quality (26). Short-term effects of being awake and vigorous and increased feelings of pleasure and comfort, besides high-uptake effects sleep disorders. The findings in our study were similar to the studies.

Increased caffeine consumption restlessness, irritability, tremor, anxiety, sleep disorders, and nausea were observed. The long-term use caused various conditions such as anxiety disorders, depression. The effects on life were investigated $(15,18,24,25,27-30)$. On the contrary, when caffeine consumption, leading to physical and psychological dependence, was discontinued, the search behavior increased to get rid of the unpleasant effects that prevented the activities of daily life and changed the normal course of life $(1,6,25,36)$. The evaluation of substance uses according to the addiction profile index subscales revealed a significant difference between the effects of black tea use on life and craving subscales, and supports the present findings.

The use of caffeine in daily life to varying degrees and versatility suggested that caffeine use disorders could not be identified in DSM-5.

It is a limitation that our study did not include all students and was conducted as a single center. According to the results of our study, it may be important to raise the awareness of the society by taking into account the risk of addiction profile especially in eastern cultures where black tea is consumed. Considering that caffeine may also be black tea origin, our study may highlight cultural studies and studies on caffeine consumption studies.

\section{Referances}

1) Turhan $E$, İnandı $T$, Özer $C$, Akoğlu S. Üniversite öğrencilerinde madde kullanımı, şiddet ve bazı psikolojik özellikler. Türkiye Halk Sağlığı Dergisi 2011;9(1):33-44.

2) Lanier C.A., Nicholson T., Duncan D.; "Drug use and mental well being among a sample of undergraduate and graduate college students", J Drug Educ 2001; 31(3):239-248.

3) Çamur D, Üner S, Çilingiroğlu N, Özcebe H. Bir Üniversitenin Bazı Fakülte ve Yüksek Okullarında Okuyan Gençlerde Bazı Risk Alma Davranışları. Toplum Hekimliği Bülteni. 2007;26(3): 32-38

4) Azad MC, Fraser K, Rumana N, Abdullah AF, Shahana N. Sleep Disturbances among Medical Students: A Global Perspective. JCSM 2015;11(1):69-74.

5) Tseng HC, Wang CJ, Cheng SH, Sun ZJ, Chen PS et al. Tea-drinking habit among new university students: Associated factors. Kaohsiung Journal of Medical Sciences 2014; 30: 98-103.

6) Yalçın M, Eşsizoğlu A, Akkoç H, Yaşan A, Gürgen F. Dicle Üniversitesi Öğrencilerinde Madde Kullanımını Belirleyen Risk Faktörleri. Klinik Psikiyatri 2009;12:125-133.

7) Williams TM, Aderanti RA. Sleep as a determinant of academic performance of university students in Ogun State, South west, Nigeria. European Scientific Journal 2014;10(13):657-664.

8) Bağımlılık Profil İndeksi’nin (BAPİ) Geliştirilmesi, Geçerlik ve Güvenilirliği. Ogel K, Evren C, Karadă̆ F, Gurol T. Defne. Türk Psikiyatri Dergisi 2012; 23(4):264-273.

9) Karataş KS. Substance Use Disorder and Sleep. Psychiatry and Clinical Psychopharmacology 2018;28(Suppl.1):326. 
10) Kacar B. Çay ve Çay Topraklarının Kimyasal Analizleri, I. Çay Analizleri. Çay İşletmeleri Genel Müdürlüğü, No:14, s.331, Çaykur Yayını, 1991, Ankara.

11)Hicks MB, Hsieh P, Bell LN. Tea preparation and its influence on methylxanthine concentration. Food Research Infernational 1996; 29: 325-330.

12) Shimbo M, Nakamura K, Jing Shi H, Kizuki M, Seino K, et al. Green tea consumption in everyday life and mental health. Public Health Nutr 2005;8:1300e6.

13)Fisunoğlu M, Besler HT. Çay ve Sağlık İlişkisi. Sağlık Bakanlığı Yayın No: 727, Klasmat Matbaacılık, 2008, Ankara.

14)De Bruin EA, Rowson MJ, Buren LV, Rycroft JA, Owen GN. Black tea improves attention and self-reported alertness. Appetite 2011;56: 235-240.

15)Ergün S, Duran S, Gültekin M, Yanar S. Sağlık Yüksekokulu Öğrencilerinde Uyku Alışkanlığ1 ve Kalitesini Etkileyen Faktörlerin Değerlendirilmesi. TJFMPC 2017; 11(3):186-193.

16) Kerpershoek ML, Antypa N, Van den Berg JF. Evening use of caffeine moderates the relationship between caffeine consumption and subjective sleep quality in students. J Sleep Res. 2018;e12670.

17)Ian Clark I, Landolt HP. Coffee, Caffeine, and Sleep: A Systematic Review of Epidemiological Studies and Randomized Controlled Trials. Sleep Medicine Reviews (2016), doi:10.1016/j.smrv.2016.01.006.

18) Güleç G, Köşger F, Eşsizoğlu A. DSM-5'te Alkol ve Madde Kullanım Bozuklukları. Psikiyatride Güncel Yaklaşımlar 2015; 7(4):448-460.

19)Karaçam Ö, Totan T. Ege Üniversitesi öğrencileri arasında bağımlılık yapıcı madde kullanımının çok boyutlu ölçekleme yöntemiyle incelenmesi. Anadolu Psikiyatri Derg 2014;15:116-123.

20)Kılıç M. Belirti Tarama listesinin geçerliliği ve güvenirliliği. Psikolojik danışma ve rehberlik dergisi. 1991;2(1):45-52.

21) Ağargün MY, Kara H, Anlar O. Pittsburgh uyku kalitesi indeksinin geçerliği ve güvenirliği. Türk Psikiyatri Dergisi 1996; 7(2):107-115.

22)Leyla Khorshid L, Sarı D. Üniversite Çalışanlarında Kafein Tüketimi. Ege Üniversitesi Hemşirelik Fakültesi Dergisi 2013; 29 (1): 45-59.

23)Loyacano SL (1999). The relationship between caffeine consumption and study habits. School Administrator, 56: 3, 6-12.

24)Hancı M, Bakırcı S, Bayram S, Karahan S, Kaya E. Türk Kahvesi ve Türkiye'de Satılan Bazı İçeceklerdeki Kafein Miktarları. DÜZCE TIP DERGİSİ 2013; 15(3): 34-38.

25)Magdalena Górnicka M, Pierzynowska J, Kaniewska E, Kossakowska K, Woźniak A. School pupils and university students surveyed for drinking beverages containing caffein. Rocz Panstw Zakl Hig 2014;65(2):113-117.

26)Zunhammer M, Eichhammer P, Busch V. Sleep Quality during Exam Stress: The Role of Alcohol, Caffeine and Nicotine. PLOS ONE 2014; 9(10) e109490.

27)Herken H, Bodur S, Kara F. Üniversite Öğrencisi Kızlarda Madde Kullanımı İle Kişilik ve Ruhsal Belirti İlişkisi. Klinik Psikiyatri; 2000;3:40-45. 
28) James Bawo O, Omoaregba Joyce O, Igberase Osayi O. Prevalence and correlates of poor sleep quality among medical students at a Nigerian university. Annals of Nigerian Medicine 2011; 5(1):1-5.

29)Lai P, Say Y. Associated factors of sleep quality and behavior among students of Two Tertiary Institutions in Northern Malaysia. Malaysia 2013; 68(3): 196-203.

30) Kang J, Chen S. Effects of an irregular bedtime schedule on sleep quality, daytime sleepiness, and fatigue among university students in Taiwan. BMC Public Health 2009; 9(248): 1-6.

31) Hisler G, Krizan Z. Anger tendencies and sleep: Poor anger control is associated with objectively measured sleep disruption. Journal of Research in Personality 2017;71: 17-26.

32)Pedersen W C, Denson T F, Goss R J, Vasquez E A, Kelley N J et al. The impact of rumination on aggressive thoughts, feelings, arousal, and behaviour. British Journal of Social Psychology 2011;50:281-301.

33) Krizan, Z., \& Hisler, G. C. The essential role of sleep in self-regulation. In K. D. Vohs \& R. F. Baumeister (Eds.), Handbook of self-regulation 3rd ed..2016, New York.

34) Street NW, McCormick MC, Austin B, Slopen,N, Habre R etal. Sleep duration and risk of physical aggression against peers in urban youth. Sleep Health 2016;2:129-135.

35)Saygılı S, Çil Akıncı A, Arıkan H, Dereli E. Üniversite öğrencilerinde uyku kalitesi ve yorgunluk. Electronic Journal of Vocational Colleges Aralık 2011; 88-94.

36)Sözlü S, Yılmaz B, Acar Tek N. Kahve Tüketimi ve Bazı Hastalıklarla İlișkisi Coffee Consumption and Relation with some Diseases. Sdü Sağlık Bilimleri Enstitüsü Dergisi 2017; 8(2):33-39. 